\title{
QUALITY ATTRIBUTES OF COOKIES PRODUCED FROM THE BLENDS OF SORGHUM, UNRIPE PLANTAIN AND WATERMELON SEED FLOURS
}

\author{
Azeez LA*1凶 iD, Adedokun S.O 1, Elutilo 00 1, Alabi A.O 1 \\ ${ }^{* 1}$ Department of Food Science and Technology, The Oke-Ogun Polytechnic Saki, Oyo State Nigeria
}

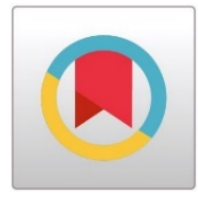

DOI: https://doi.org/10.29121/granthaalayah.v9.i2.2021.3565

Article Type: Research Article

Article Citation: Azeez LA, Adedokun S.O, Elutilo 00, and Alabi A.O. (2021). QUALITY ATTRIBUTES OF COOKIES PRODUCED FROM THE BLENDS OF SORGHUM, UNRIPE PLANTAIN AND WATERMELON SEED FLOURS. International Journal of Research -GRANTHAALAYAH, 9(2), 309-319.

https://doi.org/10.29121/granthaa layah.v9.i2.2021.3565

Received Date: 25 January 2021

Accepted Date: 27 February 2021

Keywords:

Cookies

Sorghum

Unripe Plantains

Water Melon Seed Flours

\section{ABSTRACT}

Cookies were produced from the blend of sorghum, unripe plantain and watermelon seed flours at appropriate proportion. The cookies samples were evaluated for proximate, functional, mineral and sensory qualities. Results shows ranged of values in terms of crude protein $(12.73$ - $13.47 \%)$, fat (15.07 - 15.33\%), crude fibre (0.47 - 0.81\%), ash content (2.71-5.25\%), moisture (5.25 - 6.17\%) and carbohydrate (62.09-63.56\%). The functional properties show that solubility index ranged from 20.10 51.55 , oil absorption capacity (13.00 - 21.00), water absorption capacity (15.00 - 30.45) swelling capacity (29.00 - 40.50), bulk density (21.50 80.57). The values of zinc ranged from $0.08-0.14 \mathrm{mg} / 100 \mathrm{~g}$, iron $(0.11$ $0.13 \mathrm{mg} / 100 \mathrm{~g})$, calcium $(0.11-0.13 \mathrm{mg} / 100 \mathrm{~g})$ and phosphorous $(0.17$ $0.19 \mathrm{mg} / 100 \mathrm{~g})$. Sensory evaluation of the cookies samples showed that $100 \%$ wheat flour sample was the most acceptable followed by the $90 \%$ "sorghum", 5\% plantain and 5\% water melon seed sample. Cookies produced from composite flour of sorghum, unripe plantains and water melon seed flours were found to have high nutritional value that could promotes health and wellbeing of the consumers.

\section{INTRODUCTION}

Cookies are a form of confectionery product dried to low moisture content (Okaka, 2009). Compared to biscuits, cookies tend to be larger with a softer chewier texture (IFIS, 2005). Cookies are consumed extensively all over the world as snack food and on a large scale in developing countries where protein and caloric malnutrition are prevalent (Chinma and Gernah, 2007). In Nigeria, reliance on wheat flour in the pastry and bakery industries has over the years restricted the use of other tuber crops available to domestic use. In recent years, government has through intensive collaboration with research institutes encouraged the use of composite flours in the production of bread and related food products such as biscuit. This initiative has enhanced the use of flours from cassava, sweet potato, bread-fruit, plantains and other under-utilized crops that are good sources of flour. The adoption of these locally produced flours in the bakery industry will increase the utilization of indigenous crops cultivated in Nigeria and also lower the cost of bakery products (Ayo and Gaffa, 2002). This partly stimulated research into the production of cookies using non-wheat flour blends containing functional ingredients (principally those with high dietary fiber

(C) 2021 The Author(s). This is an open access article distributed under the terms of the Creative Commons Attribution License, which permits unrestricted use, distribution, and reproduction in any medium, provided the original author and source are credited. 
and resistant starch). (Rehinan et al.,2004). Therefore, this research will investigate the effect of sorghum, unripe plantain and water melon seeds in the production of nutritional function cookies.

Sorghum (Sorghum bicolor L. Moench) is the world's fifth major cereal in terms of production and acreage. The crop is genetically suited to hot and dry agro-ecologies where it is difficult to grow other foods grains. Sorghum (Sorghum L. Moench) also known as guinea corn in West Africa and locally called Oka-baba, Dawa, and Okili in Nigeria belongs to the tribe Andropogonae (FAO. 1995). It is the fifth most important cereal crop by acreage after wheat, rice, maize, and barley globally. Sorghum grain is utilized in preparation of many traditional foods and in bakery preparations like bread, cakes cookies and biscuits (Khalil et al., 1994)

Plantain (Musa paradisiaca) It is one of the most important sources of food energy in West and Central Africa, where about 70 million people derive more than $25 \%$ of their carbohydrates from plantains (IITA, 2014). Plantain contains functional ingredients principally those with high dietary fiber in which when present in human diets lowers serum cholesterol, reduces the risk of heart attack, colon cancer, obesity, blood pressure, appendicitis and many other diseases (Rehianan et al.,2004).

Watermelon (Citrullus lanatus) a fruit crop, is an herbaceous creeping plant belonging to the family cucurbitaceae. It is mainly propagated by seeds and thrives best in warm areas. It is a major fruit widely distributed in the tropics and requires a lot of sunshine and high temperature of over $25^{\circ} \mathrm{C}$ for optimum growth (Kocheki, et al., 2007). Watermelon fruits is large, smooth and have different shapes varying from round to cylindrical. The fruit pulp serves as a thirst quencher and excellemt source of minerals, vitamins C and A (Gyner and Wehner, 2004; Tabiri, et al 2016). Researches have shown that watermelon seeds can be used considerably as a source of food for human nutrition and health: seeds are rich sources of protein, vitamins B, minerals (such as magnesium, potassium, phosphorous, sodium, iron, zinc, manganese and copper) and fat among others as well as phytochemicals and antioxidant activity phytochemicals (Braida, et al., 2012). The seeds of watermelons are known to have economic benefits especially in countries where cultivation is on the increase. The seeds are for instance used to prepare snacks, milled into flour and used for sauces. In spite of the various potential applications, the watermelon seeds are often discarded while the fruit is eaten.

\section{MATERIALS AND METHODS}

\subsection{MATERIALS AND SAMPLE PREPARATION}

The sorghum, unripe plantain and water melon were purchased from Owode market sanngo Saki Oyo State of Nigeria. The sorghum grains were sorted to remove dirt and foreign materials. They were washed severally with clean water and dried to a moisture content of $10-12 \%$ and the grains was dry milled, sieved and packaged in an air tight container until ready for used. The unripe plantain fruits were peeled and sliced to about $5 \mathrm{~mm}$ thin. The plantain slices were then dry in a cabinet dryer at 60C for $24 \mathrm{~h}$ within 15-20 min. Thereafter, the chips were milled into flour and sieved with a screen of $0.21 \mathrm{~mm}$ aperture size. The fresh water melon fruits were washed thoroughly in cleaned water and cut opened with a clean stainless knife and the seeds were extracted, washed severally to separate it from the juice and dried at temperature of $60^{\circ} \mathrm{C}$ for $6 \mathrm{~h}$. The dried seeds were milled with a mechanical blender packed in an air tight container and stored at room temperature $\left(25^{\circ} \mathrm{C}\right)$ for further analysis.

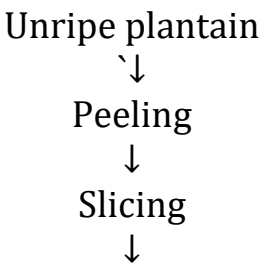

Soaking $(1 \%)$ potassium metabisulphite solution

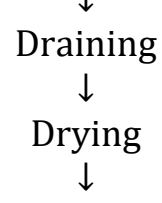


Azeez LA, Adedokun S.O, Elutilo 00, and Alabi A.O

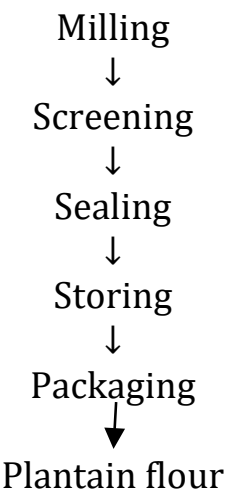

Figure 1: Flow chart for production of unripe plantain flour

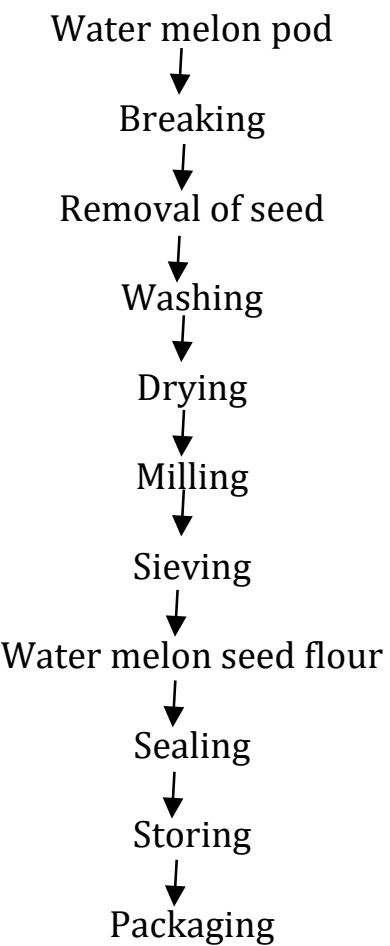

Figure 2: Flow chart for production of water melon flour

Sorghum grain

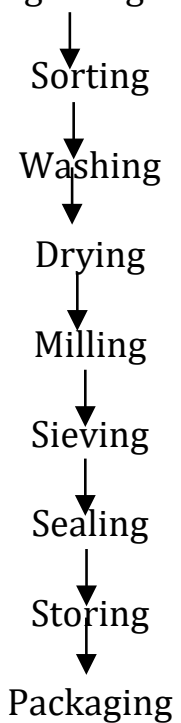

Figure 3: Flow chart for production of sorghum flour 


\subsection{RECIPE FORMULATION}

Composite flour with different proportion of sorghum, unripe plantain and water melon seed flour blends were prepared as shown in Table 1. The flour samples were blended into different ratios of 90: 5: 5, 85:10: 5 and 75: 15: $10 \%$ respectively. Wheat flour (100\%) was used as control (Table 1 )

\begin{tabular}{|c|c|c|c|c|}
\hline Sample code & Wheat (\%) & Sorghum flour (\%) & Unripe plantain flour (\%) & Water melon seed flour (\%) \\
\hline AOO & 100 & 0 & 0 & 0 \\
\hline AOB & 0 & 90 & 5 & 5 \\
\hline AOC & 0 & 85 & 10 & 5 \\
\hline AOD & 0 & 75 & 15 & 10 \\
\hline
\end{tabular}

\subsection{PRODUCTION OF COOKIES}

The cookies were prepared using the method described by (Joel, et al., 2014) with slight modifications. The flour $(500 \mathrm{~g})$, sugar $(150 \mathrm{~g})$, baking fat $(200 \mathrm{~g})$, baking powder $(2.5 \mathrm{~g})$, water $(125 \mathrm{ml})$, vanilla liquid $(20 \mathrm{ml})$, nut meg $0.9 \mathrm{~g}$, powdered milk $15 \mathrm{~g}$ and salt $(3 \mathrm{~g})$. The varying proportions of flour were weighed and mixed together with the dry ingredients, mixed with butter and creamed. Water was added and mixed properly, until good textured, slightly firm dough was obtained. The dough was rolled into a sheets and cut into shapes of $6 \mathrm{~cm}$ diameter using the stamp cutting method. The cut dough pieces were transferred into fluid fat greased pans and baked at $185^{\circ} \mathrm{C}$ for 20 min, cooled and packaged in polyethylene bags until needed.

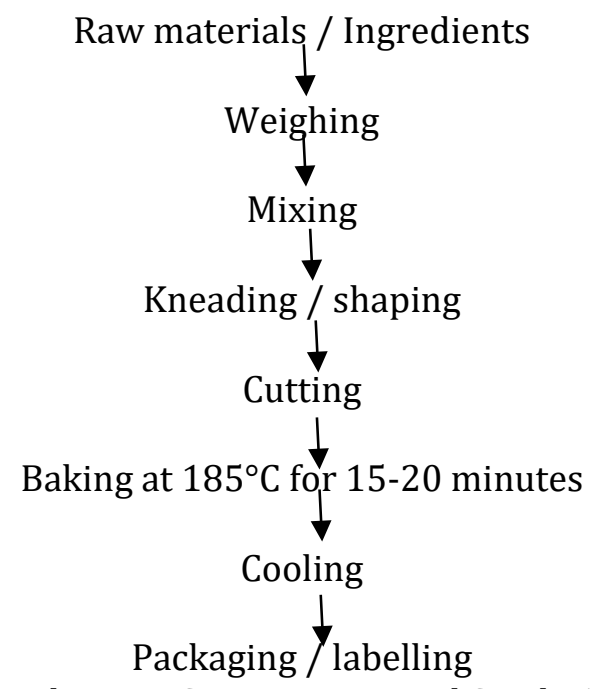

Figure 4: Flow chart for biscuit production. Source: Faris and Singh, 1990; Ayo et al., 2010; Odedeji and Adeleke, 2010.

\subsection{ANALYSES}

\subsubsection{PHYSICAL PARAMETERS}

The diameter from the physical parameters of cookies was determined by placing six cookies edge to edge and by measuring it with ruler of $\mathrm{mm}$ and by rotating at an angle of $90^{\circ}$ and the thickness by placing six cookies on top of one another based on method of AACC (2000). Spread ratio was determined from the calculated ratio of weight to thickness. 


\subsection{PROXIMATE ANALYSES}

Proximate analyses (The crude protein content, moisture content, the crude fat, crude fiber, and ash content) were determined on the cookies produced from the composite flour and wheat flour according to the standard methods of (AOAC, 2000). The carbohydrate content was determined by difference as follows: $100-($ ash + protein + fiber + fat + moisture) .

\subsection{MINERAL ANALYSIS}

Selected minerals including iron, calcium, zinc and phosphorus were extracted from dry ash samples and determined by atomic absorption spectrophotometer. AAS (AOAC, 2012)

\subsection{Functional properties}

\subsubsection{WATER ABSORPTION CAPACITY}

The method of Onwuka (2005) was adopted in the determination of water absorption capacity. One (1g) gram of sample was weighed into a conical graduated centrifuge tube and thoroughly mixed with $10 \mathrm{ml}$ distilled water for 30 seconds using a warring whirl mixer. The sample was then allowed to stand for 30 minutes at room temperature and then centrifuged at 5,000rpm for 30 minutes. The volume of free water (supernatant) was read directly from the graduated centrifuge tube. Absorption capacity is expressed as grams of water absorbed (or retained) per gram sample.

Water absorption capacity $=$ Amount of water absorbed total-free $\times$ density water

$$
\text { WAC }=\frac{\text { Weight tube }+ \text { sediment }- \text { weight of empty tube }}{\text { Weight of sample }}
$$

\subsubsection{OIL ABSORPTION CAPACITY}

The method of Onwuka (2005) was adopted in the determination of oil absorption capacity. One (1g) gram of sample was weighed into a conical graduated centrifuge tube and thoroughly mixed with $10 \mathrm{ml}$ of oil for 30 seconds using a warring whirl mixer. The sample was then allowed to stand for 30minutes at room temperature and then centrifuged at 5,000rpm for 30minutes. The volume of free oil (supernatant) was read directly from the graduated centrifuge tube. Absorption capacity is expressed as grams of oil absorbed (or retained) per gram sample.

Oil absorption capacity $=$ Amount of oil absorbed total-free $\times$ density oil

\subsubsection{BULK DENSITY}

The method of Onwuka, (2005) was adopted in the determination of bulk density. Bulk densities of samples were determined by weighing $25 \mathrm{ml}$ capacity graduated measuring cylinder, gently filling the cylinder with the sample and tapping the bottom of the cylinder on the laboratory bench several times until there is no further diminution of the sample level after filling the $25 \mathrm{ml}$ mark. The final volume is expressed as $\mathrm{g} / \mathrm{ml}$.

\subsubsection{FOAM CAPACITY}

The method of Onwuka, (2005) was adopted in the determination of foam capacity. From the powdered sample, $2.00 \mathrm{~g}$ were weighed, blended with $100 \mathrm{~cm} 3$ of distilled water using blender for $5 \mathrm{~min}$. The mixture was then poured into a $100 \mathrm{~cm} 3$ measuring cylinder and its volume was recorded after 30s. Foam capacity was expressed as percent increase in volume using the formula

Volume after whipping - volume before whipping Foam capacity $=\times 100$ Volume before whipping and the suspension was whipped 


\subsection{SENSORY EVALUATION}

The samples were presented as coded samples to 20 semi-trained panelists. The samples were randomly presented to the panelist. The panelists were given enough water to rinse their mouths in between each sample and were asked to indicate their observations using a 9-point hedonic scale for colour, taste, texture, flavor, sweetness, crunchiness, appearance and overall acceptability

\subsection{STATISTICAL ANALYSIS}

All data obtained from this study were subjected to analysis of variance (ANOVA), and means were separated using Duncan's multiple range test. SPSS software version 15 was used for all statistical analysis.

\section{RESULTS AND DISCUSSION}

\subsection{PHYSICAL PROPERTIES}

The physical properties of the cookies samples are shown in Table 3.1. Results showed that in all the parameters analyzed for physical properties, sample AOD having the maximum value while sample AOO (control) $100 \%$ wheat flour having the minimum. Moreover, with the exception of thickness in which samples AOB and AOC were not significantly difference from each other, significant differences $(\mathrm{p} \leq 0.05)$ existed in all the samples analyzed for physical properties. Dhankhar, (2003) reported spread ratio as significant properties of the cookies. The Maximum spread ratio values 7.52, 7.46 and 6.70 obtained for samples AOD, AOC and AOB, respectively compare to the value (6.15) obtained for $100 \%$ wheat flour (control sample) cookies in spread ratio, indicate that the starch in wheat flour were highly hydrophobic in nature.

\section{Physical Properties}

\begin{tabular}{|c|c|c|c|c|}
\hline Samples & Weight & Thickness & Diameter & Spread Ratio \\
\hline AOO & $4.12^{\mathrm{d} \pm 0.01}$ & $0.67^{\mathrm{c}} \pm 0.01$ & $4.80^{\mathrm{d}} \pm 0.01$ & $6.15^{\mathrm{d}} \pm 0.01$ \\
\hline AOB & $4.76^{\mathrm{c}} \pm 0.01$ & $0.69^{\mathrm{b}} \pm 0.01$ & $4.84^{\mathrm{c}} \pm 0.01$ & $6.70^{\mathrm{c}} \pm 0.01$ \\
\hline AOC & $5.22^{\mathrm{b}} \pm 0.01$ & $0.70^{\mathrm{b}} \pm 0.01$ & $4.86^{\mathrm{b}} \pm 0.01$ & $7.46^{\mathrm{b}} \pm 0.01$ \\
\hline AOD & $5.49^{\mathrm{a}} \pm 0.01$ & $0.73^{\mathrm{a}} \pm 0.01$ & $4.88^{\mathrm{a}} \pm 0.01$ & $7.52^{\mathrm{a}} \pm 0.01$ \\
\hline
\end{tabular}

AO0 - 100\% wheat flour (control)

AOB - $90 \%$ sorghum flour, $5 \%$ unripe plantain flour, $5 \%$ water melon seed flour

AOC - $85 \%$ sorghum flour, $10 \%$ unripe plantain flour, $5 \%$ water melon seed flour

AOD - $75 \%$ sorghum flour, $15 \%$ unripe plantain flour, $10 \%$ water melon seed flour

\subsection{PROXIMATE COMPOSITION OF COOKIES}

The results obtained from the proximate composition of the cookies produced from sorghum, plantains and water melon seed composite flour is presented in Table 3.2. The protein content of the cookies significantly ranged from $12.73 \%$ to $13.47 \%$. Cookies prepared at ratio $75 \%$ sorghum flour, $15 \%$ unripe plantain flour, $10 \%$ water melon seed flour had the highest Protein content. The protein content of the cookies produced from the composite flour was higher than the protein content of the cookies produced from $100 \%$ wheat flour. The protein content of the cookies increases with increasing in the percentage substitution of unripe plantain and watermelon seed flour in the cookies dough blends. Significant difference $(\mathrm{p}<0.05)$ exists among the samples. The values $(12.73 \%$ to 13.47\%) obtained are higher than 1.14 - $3.69 \%$ reported by Racheal and Margaret (2016) for quality characteristics of cookies produced from composite flours of unripe plantain, wheat and watermelon seed.

The fat content of cookies ranged from $15.07 \%$ to $15.33 \%$. The blend AOD (75:15:10 \% for sorghum, plantains and water melon seed flour; respectively) had the highest fat content while sample AOO (control) $100 \%$ wheat flour had the lowest. There was significant difference $(\mathrm{p} \leq 0.05)$ in fat content among the blends. These values $(15.07 \%$ to $15.33 \%$ ) were higher than the findings of 12.96-15.21\% reported by Giwa and Ikujenlola (2010) for biscuits 
produced from composite flours of wheat and quality protein maize. Fat content of the cookies were within the standard value for soft dough biscuits. Fats are an integral part of cookies being the third largest component after flour and sugar. Cookies are in fact a rich source of fat and carbohydrates hence, are energy giving food (Kure et al., 1998).

The crude fiber content of the cookies samples significantly ranged from $0.47 \%$ to $0.81 \%$ with the least value observed in the cookies prepared from $100 \%$ wheat flour. There was significant difference $(\mathrm{p} \leq 0.05)$ in crude fiber content among the blends. Ash content ranged from $2.71 \%$ to $5.25 \%$. Cookies prepared at $100 \%$ wheat flour had the highest ash content. The ash content ( $2.71 \%$ to $5.25 \%$ ) of the cookies reported in this study was higher than the ash content (0.64 - 1.17\%) of wheat-plantain-soy bread and plain wheat biscuits reported by Olaoye et al., (2006)

Moisture content varied from 5.25 to $6.17 \%$. Cookies produced from the blend of sorghum, plantains and water melon seed flour had the highest moisture content (6.17\%) compare with the moisture content (5.25\%) of the cookies produced from $100 \%$ wheat flour. There was significant difference $(\mathrm{p} \leq 0.05)$ in moisture content among the blends. This result (5.76 to 6.17\%) is lower with 9.37-10.03\% reported for biscuits from maize-pigeon pea flour blends by Echendu et al. (2004). Cookies are generally low moisture foods. This moisture range would improve the shelf life and acceptability of the products.

The carbohydrates content of the cookies significantly ranges between $62.09 \%$ to $62.56 \%$. The blend AOC had least carbohydrates content while AOB had the highest. Samples AOC and AOD were not significantly $(\mathrm{p}<0.05)$ different. This results (62.09\% to $63.56 \%$.) was higher with 59.71 - 70.64\% reported for cookies made from composite flours of unripe plantain, wheat and watermelon seed flour blends by Racheal and Margaret, (2016)

Table 3.2: Proximate composition of Cookies

\begin{tabular}{|c|c|c|c|c|c|c|}
\hline Samples & $\begin{array}{c}\text { Protein } \\
\text { Content }(\%)\end{array}$ & $\begin{array}{c}\text { Fat Content } \\
(\%)\end{array}$ & $\begin{array}{c}\text { Fibre Content } \\
(\%)\end{array}$ & $\begin{array}{c}\text { Ash Content } \\
(\%)\end{array}$ & $\begin{array}{c}\text { Moisture } \\
\text { Content (\%) }\end{array}$ & $\begin{array}{l}\text { Carbohyrate } \\
\text { Content (\%) }\end{array}$ \\
\hline $\mathrm{AO0}$ & $12.73^{\mathrm{d}} \pm 0.01$ & $15.07 \mathrm{a} \pm 0.01$ & $0.47^{\mathrm{d}} \pm 0.01$ & $5.25^{\mathrm{a}} \pm 0.01$ & $5.25^{\mathrm{d}} \pm 0.01$ & $63.56^{a} \pm 0.01$ \\
\hline $\mathrm{AOB}$ & $13.13^{\mathrm{b}} \pm 0.01$ & $15.21^{c} \pm 0.01$ & $0.53^{c} \pm 0.01$ & $2.71^{\mathrm{d} \pm 0.01}$ & $5.87 \mathrm{~b} \pm 0.01$ & $62.56^{\mathrm{b}} \pm 0.01$ \\
\hline AOC & $13.47 \mathrm{a} \pm 0.01$ & $15.16^{\mathrm{a}} \pm 0.01$ & $0.74^{\mathrm{b}} \pm 0.01$ & $2.84^{b} \pm 0.01$ & $5.76^{c} \pm 0.01$ & $62.09 \mathrm{c} \pm 0.01$ \\
\hline AOD & $12.83^{c} \pm 0.01$ & $15.33^{\mathrm{b}} \pm 0.01$ & $0.81^{\mathrm{a}} \pm 0.01$ & $2.77^{c} \pm 0.01$ & $6.17^{\mathrm{a}} \pm 0.01$ & $62.10^{c} \pm 0.01$ \\
\hline
\end{tabular}

AOO - 100\% wheat flour (control)

AOB - $90 \%$ sorghum flour, $5 \%$ unripe plantain flour, $5 \%$ water melon seed flour

AOC - $85 \%$ sorghum flour, $10 \%$ unripe plantain flour, $5 \%$ water melon seed flour

AOD - $75 \%$ sorghum flour, $15 \%$ unripe plantain flour, $10 \%$ water melon seed flour

\subsection{MINERAL COMPOSITION}

The results of mineral composition of cookies samples are presented in Table 3.3. The value for zinc content $(0.09$ to $0.14 \mathrm{mg} / 100 \mathrm{~g})$ and iron content $(0.12$ to $0.13 \mathrm{mg} / 100 \mathrm{~g})$ of the composite cookies was higher than the value 0.08 and $0.11 \mathrm{mg} / 100 \mathrm{~g}$, respectively obtained for the control $(100 \%)$ wheat flour. There were no significant differences in all the mineral content of the samples. Calcium content varied from 0.11 to $0.13 \mathrm{mg} / 100 \mathrm{~g}$. Sample AOC having the highest value. Phosphorous content of the samples increased significantly from 0.17 to $0.19 \mathrm{mg} / 100$ g. The lowest values were recorded for samples AOB and AOO (control (100\%) wheat flour).

Table 3.3: Mineral Composition of Cookies

\begin{tabular}{lcccc}
\hline Samples & Zinc mg/100 g & Iron mg/100 g & Calcium mg/100 g & Phosphorous mg/100 g \\
\hline AOO & $.08^{\mathrm{a}} \pm 0.01$ & $.11^{\mathrm{a}} \pm 0.01$ & $.11^{\mathrm{a}} \pm 0.01$ & $.17^{\mathrm{a}} \pm 0.01$ \\
& & & & \\
AOB & $.14^{\mathrm{a} \pm 0.01}$ & $.12^{\mathrm{a} \pm 0.01}$ & $.11^{\mathrm{a} \pm 0.01}$ & $.17^{\mathrm{a} \pm 0.01}$
\end{tabular}


Quality Attributes of Cookies Produced from The Blends of Sorghum, Unripe Plantain and Watermelon Seed Flours

$\begin{array}{lllll}\text { AOC } & .13^{\mathrm{a} \pm 0.01} & .13^{\mathrm{a}} \pm 0.01 & .13^{\mathrm{a}} \pm 0.01 & .19^{\mathrm{a}} \pm 0.01 \\ \text { AOD } & .09^{\mathrm{a}} \pm 0.01 & .12^{\mathrm{a}} \pm 0.01 & .12^{\mathrm{a}} \pm 0.01 & .18^{\mathrm{a}} \pm 0.01\end{array}$

AO0 - 100\% wheat flour (control)

AOB - $90 \%$ sorghum flour, $5 \%$ unripe plantain flour, $5 \%$ water melon seed flour

AOC - $85 \%$ sorghum flour, $10 \%$ unripe plantain flour, $5 \%$ water melon seed flour

AOD - $75 \%$ sorghum flour, $15 \%$ unripe plantain flour, $10 \%$ water melon seed flour

\subsection{FUNCTIONAL PROPERTIES OF COOKIES}

The results of functional properties of cookies samples are presented in Table 3.4. With the exception of oil absorption capacity all other functional parameters analyzed for composite flour was higher than the corresponding values obtained for $100 \%$ wheat flour, The solubility index of the composite flour ranges between 36.35 to $51.55 \%$. Flour with 85:10:5 \% had the highest solubility (51.55\%) while 90:5:5 \% flour had lowest solubility index (36.35\%). There were no significant differences in all the functional properties of the samples.

The oil absorption capacity of 100\% wheat flour (21.00) was highest than all the composite samples blends flour, while 90:5:5 \% flour had lowest $13.50 \%$ ). Abu et al., (2006) Oil absorption in starch relies predominantly on the physical entrapment of oil within the starch structure as starch does not possess nonpolar sites compared to those found in proteins.

The water absorption capacity of the blends ranges between 23.00 to $30.45 \%$. Flour sample with AOB had the highest water absorption capacity (30.45). while $100 \%$ flour had the lowest water absorption capacity (15.00). The WAC is the ability of a product to associate with water under limiting conditions in order to improve its handling characteristics and dough making potentials (Singh et al., 2001; Giami, 2004))

The swelling capacity of composite flour varied from 29.00 to $40.50 \%$. Sample AOC having the least swelling capacity (29.0\%), while sample AOB having the highest (40.50\%). Achinewhu et al., (1998) reported that high swelling capacity has been reported as part of the criteria for a good quality product.

The bulk density of $100 \%$ wheat flour was highest than all the composite samples blends. The bulk density of the flour ranges between $21.50-26.50 \%$. Flour sample with AOC had the highest $(26.50 \%)$ while 80:15:5\% had the lowest. Significant difference $(\mathrm{p}<0.05)$ exists among the samples. Values observed for the bulk density of the cookies in this study are higher to those reported (0.76 - 0.82) by Racheal and Margaret (2016) for cookies produced using unripe plantain, wheat and watermelon seed flour blends. Lewis, (1990) bulk density gives an indication of the relative volume of packaging material required and high bulk density is a good physical attribute when determining the mixing quality of a particulate matter.

Table 3.4: Functional Properties of Cookies

\begin{tabular}{|c|c|c|c|c|c|}
\hline Samples & SI & OAC & WAC & SC & $\mathrm{BD}$ \\
\hline $\mathrm{AOO}$ & $20.10^{\mathrm{d}} \pm 0.01$ & $21.00^{\mathrm{a} \pm 0.01}$ & $15.00^{\mathrm{d}} \pm 0.01$ & $29.75^{c} \pm 0.01$ & $80.57 a \pm 0.01$ \\
\hline AOB & $36.35^{c} \pm 0.01$ & $13.50^{\mathrm{d}} \pm 0.01$ & $30.45^{\mathrm{a}} \pm 0.01$ & $40.50^{a} \pm 0.01$ & $23.50^{c} \pm 0.01$ \\
\hline AOC & $51.55^{\mathrm{a}} \pm 0.01$ & $15.50^{c} \pm 0.01$ & $23.00^{c} \pm 0.01$ & $29.00^{d} \pm 0.01$ & $26.50^{\mathrm{b}} \pm 0.01$ \\
\hline AOD & $51.45^{\mathrm{b}} \pm 0.01$ & $17.00^{\mathrm{b}} \pm 0.01$ & $29.00^{b} \pm 0.01$ & $33.50^{\mathrm{b}} \pm 0.01$ & $21.50^{\mathrm{d}} \pm 0.01$ \\
\hline
\end{tabular}

A00 - 100\% wheat flour (control)

AOB - $90 \%$ sorghum flour, $5 \%$ unripe plantain flour, $5 \%$ water melon seed flour AOC - $85 \%$ sorghum flour, $10 \%$ unripe plantain flour, $5 \%$ water melon seed flour AOD - $75 \%$ sorghum flour, $15 \%$ unripe plantain flour, $10 \%$ water melon seed flour 


\subsection{SENSORY PROPERTIES OF THE COOKIES}

The result of sensory properties of cookies is presented in Table 3.5. The results of the sensory evaluation showed that $100 \%$ wheat cookies had the best attributes for, crispness, appearance and texture. The most preferred cookies with respect to the taste (8.85\%) were the ones with inclusion of $90 \%$ sorghum flour, $5 \%$ unripe plantain flour and $5 \%$ water melon seed flour. There was significant difference in taste and crispness of cookies produced. However, it was observed that there were no significant differences ( $p>0.05$ ) in samples AOB and AOC in appearance and overall acceptability of the cookies. The overall Acceptability revealed that the cookies from $100 \%$ wheat flour (control) was the most acceptable (7.95). This could be as a result of familiarity with $100 \%$ wheat flour, followed by the cookies produced from the inclusion of $75 \%$ sorghum flour, $15 \%$ unripe plantain flour and $10 \%$ water melon seed flour. while sample AOC (85\% sorghum flour, $10 \%$ unripe plantain flour, $5 \%$ water melon seed flour) having the least overall acceptability.

Table 3.5: Sensory Properties of the cookies

\begin{tabular}{lccccc}
\hline Samples & Appearance & Taste & Crispness & Texture & Overall Acceptability \\
\hline AOO & $7.40^{\mathrm{a}} \pm 0.10$ & $7.55^{\mathrm{b}} \pm 0.10$ & $6.90^{\mathrm{a}} \pm 0.10$ & $8.55^{\mathrm{a}} \pm 0.10$ & $7.95^{\mathrm{a}} \pm 0.10$ \\
AOB & $5.90^{\mathrm{b} \pm 0.10}$ & $8.85^{\mathrm{a}} \pm 0.10$ & $5.95^{\mathrm{b}} \pm 0.10$ & $6.05^{\mathrm{b} \pm 0.10}$ & $7.65 \mathrm{~b}^{\mathrm{b}} \pm 0.10$ \\
& & & & & \\
AOC & $5.80^{\mathrm{b} \pm 0.10}$ & $5.50^{\mathrm{c} \pm 0.10}$ & $5.45 \mathrm{c}^{\mathrm{c}} \pm 0.10$ & $5.65^{\mathrm{c} \pm 0.10}$ & $7.05^{\mathrm{b} \pm 0.10}$ \\
& & & & & \\
AOD & $5.00^{\mathrm{c}} \pm 0.10$ & $4.80^{\mathrm{d}} \pm 0.10$ & $5.05^{\mathrm{d}} \pm 0.10$ & $4.70^{\mathrm{c}} \pm 0.10$ & $7.30^{\mathrm{c} \pm 0.10}$
\end{tabular}

AO0 - 100\% wheat flour (control)

AOB - $90 \%$ sorghum flour, $5 \%$ unripe plantain flour, $5 \%$ water melon seed flour AOC - $85 \%$ sorghum flour, $10 \%$ unripe plantain flour, $5 \%$ water melon seed flour AOD - $75 \%$ sorghum flour, $15 \%$ unripe plantain flour, $10 \%$ water melon seed flour

\section{CONCLUSION}

The study has shown that acceptable cookies can be formulated from composite of sorghum flour, unripe plantain flour, and water melon seed flour blends. The protein content of the cookies increased significantly with the increased in substitution level of sorghum, unripe plantain and water melon seed flour. In term of consumer acceptability cookies prepared from $75 \%$ sorghum flour, $15 \%$ unripe plantain flour, $10 \%$ water melon seed flour were compare favorably with cookies made from $100 \%$ wheat flour. Cookies made from composite flour have highest content of all the mineral than cookies made from $100 \%$ wheat flour (control). Therefore, composite cookies from various substitution level of sorghum, unripe plantain and water melon seed flour were more nutritious than $100 \%$ cookies produced from the wheat flour. More research should also be carried out on the ant nutrients properties of the various flour used in this study.

\section{SOURCES OF FUNDING}

This research received no specific grant from any funding agency in the public, commercial, or not-for-profit sectors.

\section{CONFLICT OF INTEREST}

The author have declared that no competing interests exist. 


\section{ACKNOWLEDGMENT}

None.

\section{REFERENCES}

[1] AACC. (2000). Approved methods of the American Association of Cereal Chemists. Am Assoc Cereal Chem Inc St Paul. Minnesota

[2] Abu, J.O., Maller, K., Duodu, K.G. and Minnaar, A. (2006). Gamma irradiation of cowpea (Vignaunguiculata L. Walp) flours and pastes: effects on functional, thermal and Molecular properties of isolated proteins. Food Chem. 95: 138-147

[3] Achinewhu, S.C., Barber L.I. and I.O. Ijeoma, (1998). Physicochemical properties and garification (gari yield) of selected cassava cultivars in Rivers State, Nigeria Plant Food Hum. Nutr., 52: 133-140.

[4] AOAC. (2000). Association of Official Analytical Chemists, Official Methods of Analysis International, Maryland, USA

[5] AOAC. (2012). Association of Official Analytical Chemists, Official Methods of Analysis8th edition Gaithersburg, MD.

[6] Ayo, J.A., Ikuomola, D.S. and Esan, Y.O. (2010). Effect of added Defatted Beniseed on the Quality of Acha-based Biscuits. Continental journal of Food Science and Technology 4:7-13

[7] Ayo, J.A. and Gaffa, T. (2002). Effect of undeffated soybean flour on the protein content and Sensory quality of Kunnu Zaki Nig Food J. 20: 7-9

[8] Braida, W., Odiong, L. and Oranusi, M. (2012). Phytochemical antibacterial properties the seed of watermelon (Citrullus lanatus). Prime Journal of Microbiology Research, 2 (3): 99 -104

[9] Chinma, C.F. and Gernah, D.I. (2007). "Physicochemical and sensory properties of cookies Produced cassava soybean mango composite flours" Journal of raw material research 4: 32-43

[10] Dhankhar, P. (2013). Dvelopment of Coconut Based Gluten Free Cookies. International Journal of Engineering Science Invention 2 (12): 10 - 19

[11] Echendu, C.A., Onimawo, I.A. and Adieze, S. (2004). Production and evaluation of doughnut and biscuits from maize-pigeon pea flour blends. Niger, Food J., $22: 147-153$

[12] FAO. (1995). Sorghum and millet in human nutrition. FAO Food and Nutrition Series, No. 27 Food and Agriculture Organization of the United Nations, Rome;

[13] Faris, D.G. and Singh, U. (1990). Pigeon pea Nutrition and products. CAB international 401-434

[14] Giami, S.Y. (2004). Effect of fermentation on the seed proteins, nitrogenous constituents, Antinutrients and nutritional quality of fluted pumpkin (Telfaria occidentalis Hook). Food Chemistry 88(3): 397-404

[15] Giwa, E.O and Ikujenlola, A.V. (2010). Quality Characteristics of biscuits produced from Composite flours of wheat and quality protein maize. Afr. J. Food Sci. Technol., $1: 116-119$

[16] Guiner,N. and Wehner, T.C. (2004). The genes of watermelon. 39 (6): 1175 - 1182

[17] IITA. (2014). Plantain/Banana; Youth Agripreneurs, International Institute of Tropical Agriculture: Ibadan.

[18] IFIS, (2005). Dictionary of Food Science and Technology. Blackwell Publishing Oxford, U.K. 106

[19] Joel, N., Fatima, K. and Stephen, F. (2014). Production and quality assessment of enriched Cookies from whole wheat and full fat soy. European Journal of Food Science and Technology 2:19-28

[20] Khalil, J.K., Sawaya, W.N., Safi, W.J and Al-Mohammed, H.M. (1994). Chemical composition and nutritional quality of sorghum flour and bread, plant foods Human Nutr 34: 141- 150

[21] Koocheki, A., Razavi, S.M.A and Milani, E. (2007). Physical properties of weatermelon seed as a function of moisture content and variety. Int Agrophysis. 21 (4): 349 - 359

[22] Kure, O.A., Bahago, E.J., and Daniel, E.A. (1998). Studies on the proximate composition and effect of flour particle size of acceptability of biscuits produced from plantain flours. Namoda Tech Scope J. 3:17 - 22

[23] Lewis, M.J. (1990). Physical Properties of Food and Food Processing Systems. 2nd Edn., Hartnolls Ltd., Bodmin, Cornwall.

[24] Odedeji, J.O. and Adeleke, R.O. (2010). Pastry characteristics of wheat and sweet potato flour Blends. Pakistan Journal of Nutrition 9(6): 555-557 
[25] Okaka, J.C. (2009). Handling, Storage and Processing of plant food. 2nd Edn. Academy Published English Nigeria. 132

[26] Olaoye, O.A., Onilade, A.A. and Idowu, O.A. (2006). Quality characteristics of bread produced Composite flour of wheat, plantain and soybeans. African J. Biotechnol 5(11): 1102- 1106, 35

[27] Onwuka, G.I. (2005). Soaking, boiling and antinutritional factors in Pigeon peas (Cajanus cajan and cowpeas (Vigna. Unguiculata). Journal of Food Processing and Preservation 30 (65): 616 - 650

[28] Racheal. O.O. and Margaret, A.A. (2016). Quality Characteristics of Cookies Produced from Composite Flours of Unripe Plantain, Wheat and Watermelon Seed. Indian J Nutri. 2016;2(2): 117.

[29] Rehinan, Z., Rashid., M and Shah, W.H. (2004). "Insoluble Dietary Fibre Components of Food Legumes as Affected by Soaking and Cooking Processes". Food Chemistry. 85:245-249

[30] Singh, K.K., Samanta, A.K., and Maity, S.B. (2001). Nutritional evaluation of stylo (Stylosanthes hamata) hay in goats. Indian J Anim Nutr 18(1): 96-98.

[31] Tabiri, B., Agbenorhev, J.K., Faustina, D. Wireko-Manu, F.D., and Elsa, I.O. (2016). Watermelon Seeds as Foods Nutrient Composition, Phytochemicals and Antioxidant Activity. International Journal of Nutrition and Food Sciences. 5(2): 139 - 144 